\title{
Pertanggungjawaban Negara Terhadap Pencemaran Lingkungan Transnasional
}

\author{
Deni Bram \\ Fakultas Hukum Universitas Pancasila \\ Jl. Srengseng Sawah Jagakarsa Jakarta Selatan \\ deni_up@yahoo.co.id
}

\begin{abstract}
Losses experienced by other countries as a result of smoke haze pollution made the concept of state responsibility that requires an injury to other countries is questionable again. The problems that would be investigated: first, is there any basic difference about the concept of state responsibility as the result of smoke pollution across national borders based on international law and international environmental law? Second, how is the dispute settlement mechanism related to environmental pollution which has transnational characteristicl in international environmental law? Third, is Indonesian government able to be asked for responsibility on the case of smog pollution from forest fires in Southeast Asia? This research is based on normative research in providing law material for supporting its holistic research nature. This research concludes, first, the principle of state accountability basically includes the obligation that states give impact to other countries to do reparation to the states that suffered the damage and to restore the condition. Second, the available international environmental law dispute resolution mechanism is started from the claim of the countries that suffered damages, which is a form of absorption of international law in the enforceability of the key principles in international laws. Third, Indonesian government is able to be asked for responsibility on the smog pollution that occured.
\end{abstract}

Key words : Transnational pollution, responsibility, international laws.

\begin{abstract}
Abstrak
Kerugian yang dialami negara lain sebagai akibat pencemaran kabut asap membuat konsep pertanggungjawaban negara yang mensyaratkan adanya injury bagi negara lain kembali dipertanyakan. Permasalahan yang akan diteliti: Pertama, apakah terdapat perbedaan yang hakiki mengenai konsep pertanggungjawaban negara sebagai akibat pencemaran asap lintas batas negara menurut hukum internasional dan hukum lingkungan internasional? Kedua, bagaimanakah mekanisme penyelesaian sengketa pencemaran lingkungan yang bersifat transnasional dalam hukum lingkungan internasional? Ketiga, apakah Pemerintah Indonesia dapat dimintakan pertanggungjawaban atas kasus pencemaran kabut asap akibat kebakaran hutan di Asia Tenggara? Penelitian ini didasarkan atas penelitian normatif dalam menyuguhkan bahan hukum dalam menunjang sifat holistik dari penelitian. Penelitian ini menyimpulkan, pertama, prinsip pertanggungjawaban negara pada intinya memuat kewajiban negara yang memberikan dampak kepada negara lain untuk melakukan suatu reparasi kepada negara yang dirugikan dan mengembalikan kondisi negara yang bersangkutan seperti semula. Kedua, mekanisme penyelesaian hukum lingkungan internasional yang tersedia adalah diawali dari adanya claim dari negara yang mengalami kerugian yang merupakan suatu bentuk absorpsi hukum lingkungan internasional terhadap keberlakuan prinsip utama dalam hukum internasional tersebut. Ketiga, pemerintah Indonesia dapat dimintakan pertanggungjawaban atas pencemaran kabut asap yang terjadi.
\end{abstract}

Kata kunci : Pencemaran lintas negara, tanggung jawab, hukum Internasional. 


\section{Pendahuluan}

Dalam beberapa dekade belakangan, masalah lingkungan hidup semakin besar, meluas dan serius. Persoalannya pun tidak terbatas pada tingkat lokal atau translokal, melainkan regional, nasional, transnasional dan global. Salah satu hal penting yang menjadi pokok pembicaraan pada saat itu adalah penanganan terhadap pencemaran lingkungan yang bersifat lintas batas negara atau transnasional (transboundary pollution). Terlebih pada era globalisasi yang semakin mendorong banyak negara maju untuk semakin meningkatkan kemajuan ekonomi dengan paham kapitalisme yang dimiliki sehingga berdampak pada kerugian yang harus diterima oleh negara lain baik yang terjadi sebagai suatu bentuk akibat secara langsung maupun tidak langsung.

Hal ini kemudian ditanggapi dalam hukum lingkungan internasional dengan mulai diadopsinya konsep pertanggungjawaban negara (State Responsibility) sebagai suatu bentuk pertanggungjawaban negara terhadap pencemaran yang mengakibatkan injury bagi negara lain. Ketentuan tersebut kemudian menjadi agenda penting dalam Konferensi Lingkungan Hidup Internasional yang kemudian memuat konsep ini dalam Pasal 21 Deklarasi Stockholm 1972.

"States have, in accordance with the Charter of the United Nations and the principles of international law, the sovereign right to exploit their own resources pursuant to their own environmental policies, and the responsibility to ensure that activities within their jurisdiction or control do not cause damage to the environment of other States or of areas beyond the limits of national jurisdiction"

Bentuk pertanggungjawaban negara dalam ketentuan hukum internasional digunakan untuk menggambarkan kewajiban negara melakukan ganti kerugian berupa reparasi atau kompensasi terhadap pelanggaran kewajiban internasional. ${ }^{1}$ Menurut ketentuan tentang State Responsibility yang telah dikodifikasi oleh Komisi Hukum Internasional, yang menyatakan bahwa segala bentuk tindakan salah (wrongful act) pada tingkat internasional oleh suatu negara menuntut adanya pertanggungjawaban dari negara tersebut dalam hukum internasional. ${ }^{2}$

Dalam konteks kekinian, konsep pertanggungjawaban negara menjadi salah satu isu penting yang dibicarakan pada tingkat global pada umumnya dan regional, khususnya Asia Tenggara sekarang ini. Hal ini dilatarbelakangi dengan semakin

\footnotetext{
${ }^{1}$ Alan Khee Jin Tan, Forest Fire of Indonesia : State Responsibility and Internasional Liability, Faculty of Law National University of Singapore, Singapore, 2008, hlm. 3.

${ }^{2}$ International Law Commission Draft Article on State Responsibility, ILC 2001 Report, Art. 1.
} 
hebatnya pencemaran udara yang terjadi di kawasan Asia Tenggara hingga ke daratan Australia yang disebabkan oleh kebakaran hebat yang melanda kawasan hutan Indonesia. Kabut asap yang dihasilkan dari kebakaran hutan di Indonesia dari tahun ke tahun makin akrab sebagai agenda tahunan bagi negara tetangga dan hal ini disertai pula dengan dampak ekonomis dan kesehatan yang dihasilkan dari kabut asap tersebut.

Sebagai suatu bentuk pencemaran lingkungan yang bersifat transnasional, selain memberikan dampak bagi kesehatan dan kelayakan ekosistem udara pada tingkat lokal dan nasional, kabut asap yang dihasilkan dari kebakaran hutan di Indonesia juga telah berdampak pada kelangsungan hidup dan kegiatan ekonomi pada sebagian negara lain dalam lingkup regional ASEAN. Pada awal terjadinya kebakaran hutan hebat di Indonesia pada pertengahan tahun 1997, diperkirakan kerugian materiil yang dialami oleh Indonesia, Malaysia, dan Singapura mencapai 4,5 Billion US \$ atau setara dengan Rp. 9.000.000.000,00 pada saat itu, dan sebagai puncaknya kebakaran hutan yang terjadi, Indonesia pun dinobatkan sebagai pencemar udara terbesar di dunia. ${ }^{3}$ Selain itu, dampak yang dihasilkan dari kabut asap kebakaran hutan juga memberikan efek kepada menurunnya kesehatan masyarakat sekitar terutama dampak yang mengakibatkan Infeksi Saluran Pernafasan Akut (ISPA).

Berawal dari fenomena kebakaran hutan yang hebat melanda kawasan ASEAN pada 1997/1998, para petinggi ASEAN mencoba merumuskan pola penanganan yang efektif dengan mengadakan pertemuan persiapan di Hanoi yang menghasilkan Plan of Action dan Visi ASEAN 2020. Sebagai puncak pertemuan tersebut, para pemimpin ASEAN merumuskan pola penanganan pencemaran kabut asap di Asia Tenggara dalam suatu ASEAN Agreement on Transboundary Haze Pollution (Persetujuan ASEAN tentang Pencemaran Kabut Asap Lintas Batas) yang mengatur pendistribusian tanggung jawab dan penanganan pencemaran kabut asap pada kawasan regional Asia Tenggara. Perjanjian ini ditandatangani oleh 10 negara peserta ASEAN pada Juni 2002, dan kemudian came into force pada 25 November 2003.

Setelah tiga tahun berjalan, tujuh dari sepuluh negara penandatangan telah melakukan ratifikasi dan harmonisasi dengan peraturan perundang-undangan

\footnotetext{
${ }^{3}$ Perkiraan ini dibuat pada bulan Mei 1998 oleh The Singapore based Economy and Environment Programme for Southeasat Asia (EEPSEA) dan World Wide Fund for Nature (WWF); seperti yang termuat dalam Indonesia Fires and Haze of 1997 : The Economic Tool, (1998).

${ }^{4}$ ASEAN Agreement on Transboundary Haze Pollution, Art. 29.
} 
nasional negara peserta setempat. Namun, hal ini menjadi ironis pada saat Indonesia sebagai subjek utama kebakaran hutan yang menjadi penyumbang dominan kabut asap yang dipermasalahkan dalam perjanjian tersebut, justru belum melakukan ratifikasi dengan peraturan perundang-undangan nasional hingga saat ini. Keberadaan ASEAN Agreement on Transboundary Haze Pollution seharusnya menguntungkan Pemerintah Indonesia, sehingga tidak ada alasan untuk menunda proses ratifikasi terhadap perjanjian tersebut. Bahkan menurut beberapa ahli hukum internasional, dengan melakukan ratifikasi perjanjian tersebut Indonesia akan terbebas dari pertanggungjawaban negara yang diemban. ${ }^{5}$

Sikap pemerintah Indonesia yang sampai saat ini belum meratifikasi ASEAN Agreement on Transboundary Haze Pollution (Persetujuan ASEAN tentang Pencemaran Kabut Asap Lintas Batas), secara tersirat menunjukkan tidak adanya kesungguhan (due diligence) dari pemerintahan saat ini, terlebih hal ini seakan diperkuat dengan adanya upaya legalisasi terhadap beberapa kegiatan pembakaran hutan secara liar di beberapa daerah dengan istrumen Peraturan Daerah, ${ }^{6}$ sedangkan akibat dari kabut asap yang dihasilkan telah memberikan dampak kerugian materiil dan imateriil bagi negara sekitar.

Dalam kondisi seperti ini, konsep pertanggungjawaban negara yang mensyaratkan adanya injury bagi negara lain seakan kembali dipertanyakan dengan ketentuan dalam Principle 21 Stockholm Declaration yang memberikan kedaulatan sepenuhnya kepada negara untuk mengelola sumber daya alam mereka masing masing, serta dengan prinsip common but differentiated responsibility yang diatur dalam Pasal 7 Rio Declaration dalam ketentuan hukum lingkungan internasional.

\section{Rumusan Masalah}

Pertama, apakah terdapat perbedaan yang hakiki atau prinsipil mengenai konsep pertanggungjawaban negara sebagai akibat pencemaran asap lintas batas negara menurut hukum internasional pada umumnya dan hukum lingkungan internasional pada khususnya ? Kedua, bagaimanakah mekanisme penyelesaian sengketa

${ }^{5}$ Pendapat ini dikemukakan oleh Guru Besar Hukum Internasional Fakultas Hukum Universitas Indonesia Hikmahanto Juwana, lihat Media Indoensia Online, "Indonesia belum Ratifikasi Perjanjian ASEAN", terdapat dalam situs http://www.mediaindo.co.id/RUBRIK/DEFAULT.ASP?CAT_ID=33 diakses tgl 29 Januari 2008.

${ }^{6}$ Peraturan tersebut tercantum dalam Peraturan Daerah Riau dan Peraturan Daerah Kotawaringin Barat. Lihat Deni Bram, “Kebijakan Pengelolaan Hutan Belum Proekologi”, Media Indonesia, 1 September 2007, hlm. 7. 
pencemaran lingkungan yang bersifat transnasional dalam hukum lingkungan internasional ? Ketiga, apakah Pemerintah Indonesia dapat dimintakan pertanggungjawaban atas kasus pencemaran kabut asap akibat kebakaran hutan di Asia Tenggara, apabila locus delicti terjadinya kebakaran hutan tersebut berada dalam yurisdiksi negara Indonesia ? Serta konsekuensi apa yang diemban dari Pemerintah Indonesia?

\section{Tujuan Penelitian}

Pertama, untuk mengetahui perbedaan yang hakiki atau prinsipil mengenai konsep pertanggungjawaban negara sebagai akibat pencemaran asap lintas batas negara menurut hukum internasional pada umumnya dan hukum lingkungan internasional pada khususnya, sehingga menimbulkan konsep pertanggungjawaban yang berbeda dalam tahapan teoritis dan praktis.

Kedua, menganalisis konsep penyelesaian sengketa yang dapat dilakukan dalam hal terjadinya pencemaran lingkungan yang bersifat transnasional. Sebagaimana diketahui, perkembangan hukum lingkungan internasional mengalami perkembangan yang cukup signifikan, terlebih ketika jagat raya ini menjadi suatu small village yang tidak lagi terbatas ruang dan waktu, sehingga seakan-akan telah menafikan batasbatas administrasi pemerintahan suatu negara dengan negara atau negara-negara lainnya di dunia yang sangat memungkinkan untuk timbulnya sengketa antar negara.

Ketiga, melakukan analisis terhadap kemungkinan penerapan prinsip pertanggungjawaban negara kepada negara Indonesia berkaitan dengan dampak kabut asap yang dihasilkan dari proses kebakaran hutan di Indonesia. Konsep ini juga hendak melakukan suatu kajian atas segala upaya yang telah dilakukan oleh Pemerintah Indonesia dalam upaya meminimalisir dampak dari kabut asap kebakaran hutan yang berdampak ke beberapa negara tetangga.

\section{Metode Penelitian}

Penelitian merupakan sarana yang dipergunakan manusia dalam rangka memperkuat, membina serta mengemban ilmu pengetahuan. Menurut Robert Bogdan dan Steven J Taylor seperti dikutip dalam Soerjono Soekanto, ${ }^{7}$ yang dimaksud

\footnotetext{
${ }^{7}$ Soerjono Soekanto, Pengantar Penelitian Hukum, Cet. 3, Universitas Indonesia, Jakarta, 1986, hlm. 46.
} 
dengan penelitian ilmiah adalah the process, principles and procedures by which approach problems and seek answer. In the social science, the terms to how to conduct reserach. Dalam penelitian ini, sebagian data penelitian juga berlandaskan data sekunder berupa bahan bahan hukum primer, ${ }^{8}$ yang meliputi Draft Article on Responsibility of State for Internationally Wrongful Act, ASEAN Agreement on Transboundary Haze Pollution dan 1979 Convention on Long-Range Transboundary Air Pollution.

Selain itu juga terdapat bahan hukum sekunder yang memberikan penjelasan mengenai bahan hukum primer. Dalam penelitian ini akan digunakan beberapa buku acuan yang membahas mengenai prinsip-prinsip dasar ketentuan hukum lingkungan internasional dan beberapa commentary yang berkaitan dengan kodifikasi prinsip pertanggungjawaban negara yang dikeluarkan oleh International Law Commission. Sedangkan bahan hukum tersier digunakan sebagai petunjuk maupun penjelasan terhadap bahan hukum primer dan sekunder dalam penelitian ini akan digunakan beberapa kamus hukum seperti Black's Law Dictionary, kamus besar bahasa Indonesia, kamus lingkungan dan keterangan dari Wikipedia sebagai referensi.

Bahan-bahan yang didapatkan kemudian diolah dengan menggunakan pendekatan sifat dan bentuk penelitian deskriptif - preskriptif - analitis dan dicoba untuk menggambarkan permasalahan yang terjadi yang kemudian akan dianalisis dengan situasi dan kondisi aktual yang terjadi untuk mendapatkan jawaban dari hipotesa sementara.

Selain mendasari pada data sekunder di atas, juga digunakan data primer dengan menggunakan metode wawancara kepada beberapa pihak terkait yang terdiri dari instansi pemerintah dan institusi swasta. Instansi Pemerintahan dalam hal ini diwakili oleh Kementrian Negara Lingkungan Hidup, Departemen Luar Negeri dan Departemen Hukum dan Hak Asasi Manusia yang dimaksudkan untuk mengetahui perkembangan Political Will Pemerintah Indonesia dalam menjalankan pengelolaan lingkungan pada umumnya, kelestarian hutan, penegakan hukum di bidang kehutanan dan suasana politik yang muncul dalam melakukan proses ratifikasi terhadap beberapa Multilateral Environment Agreement's di bidang Lingkungan Hidup. Sedangkan pada institusi swasta penulis melakukan wawancara kepada beberapa perusahaan yang dituding melakukan pembakaran lahan serta kepada lembaga swadaya masyarakat yang concern terhadap lingkungan hidup. 


\section{Hasil dan Pembahasan}

Prinsip pertanggungjawaban negara dalam landasan filosofis tidak terlepas dari kedaulatan yang mutlak dimiliki oleh setiap entitas yang disebut sebagai negara. Kedaulatan yang mempunyai kata dasar daulat, merupakan suatu bentuk kekuasaan tertinggi oleh suatu negara tertentu. Kedaulatan merupakan suatu hal yang sangat penting dalam menentukan eksistensi suatu negara baik dalam keberlangsungannya melakukan hubungan dengan negara lain maupun dalam mengatur warga negara di dalam teritorial wilayah negara yang bersangkutan. Walaupun dalam kenyataannya kedaulatan itu sendiri berada dalam ranah yang sangat teoretis.

Pada awalnya prinsip tanggung jawab negara berada dalam pelaksanaan secara internal, yaitu menilai sejauh mana suatu entitas negara melakukan suatu kegagalan dalam memberikan fungsi kedamaian dan kesejahteraan yang layak bagi warganya. Seperti dikemukakan dalam pengantar di atas, prinsip tanggung jawab negara selain mempunyai fungsi eksternal, juga mempunyai fungsi internal, yaitu terhadap warga negara dari negara yang bersangkutan. Perbedaan yang signifikan dari bentuk pertanggungjawaban negara terhadap warga negara adalah objek dari penerapan prinsip ini yaitu melibatkan hubungan antara negara atau pemerintah yang melaksanakan fungsi negara dengan warga negara dari negara yang bersangkutan. Di beberapa belahan dunia lain, negara mempunyai tanggung jawab untuk dapat memberikan kebebasan politik, keamanan, kesehatan, pendidikan, kesempatan kegiatan ekonomi, pelayanan yang baik, ketertiban hukum dan hak fundamental lainnya. ${ }^{9}$

Dalam ranah hukum internasional, prinsip pertanggungjawaban negara memiliki tautan erat dengan eksistensi kedaulatan negara dalam hubungan internasional sebagai salah satu prinsip utama dalam hukum internasional. Dasar kedaulatan setiap negara juga diperkuat dengan adanya doktrin persamaan derajat negara dalam hukum internasional. ${ }^{10}$ Doktrin persamaan derajat negara-negara (doctrine of the equality of States) telah dikembangkan sejak permulaan sejarah hukum internasional modern yang menekankan pentingnya hubungan antara hukum bangsa-bangsa dan hukum alam. Cristian Wolf mengungkapkan bahwa pada dasarnya semua bangsa mempunyai kedudukan yang sama satu sama lain, karena bangsa-bangsa dianggap sebagai pribadi manusia bebas yang hidup dalam suatu keadaan alami. Oleh karena itu,

\footnotetext{
${ }^{9}$ Donald W Potter, State Responsibility, Sovereignity, and Failed States, University of Tasmania, Australia, 2002, hlm. 2.

${ }^{10}$ J.G. Starke, Hukum Internasional, Edisi Kesepuluh, Sinar Grafika, Jakarta, 2006, hlm. 141.
} 
karena pada dasarnya semua manusia memiliki kedudukan yang sama, maka semua bangsa pun pada dasarnya berkedudukan sama satu sama lain. ${ }^{11}$

Seringkali walaupun telah diatur hak dan kewajibannya dalam suatu ketentuan sumber hukum internasional, seringkali tindakan yang diambil oleh suatu negara menimbulkan injury terhadap, atau penghinaan atas martabat dan kewibawaan negara lain. Pada situasi dan kondisi seperti ini, konsep pertanggungjawaban negara sebagai subjek yang dominan dalam pergaulan internasional mulai mendapatkan perhatian dari masyarakat internasional. Awal dari eksistensi dari prinsip pertanggungjawaban negara sendiri tidak terlepas dari prinsip kesetaraan dan kedaulatan yang dimiliki oleh setiap subjek hukum internasional. Prinsip ini kemudian memberikan kewenangan bagi suatu negara yang terlanggar haknya untuk menuntut reparasi. ${ }^{12}$

Dalam perkembangannya, sebagai konsekuensi logis dari prinsip persamaan dan kedaulatan negara yang terdapat dalam ketentuan hukum internasional, adalah pemberian kewenangan bagi tiap negara untuk dapat menuntut suatu bentuk pertanggungjawaban dari pihak lain dalam hal terjadinya pelanggaran hak suatu negara. hal ini kemudian diperkuat dengan adagium yang dipopulerkan oleh Grotius pada 1646 yang menyatakan, bahwa pada setiap kesalahan internasional mengakibatkan kewajiban untuk mengembalikan kerugian yang terjadi. ${ }^{13}$

Prinsip pertanggungjawaban negara dalam metamorfosisnya menjadi salah satu prinsip inti dari hukum internasional. Prinsip ini lalu berkembang pesat setelah era perang dunia. Terdapat beberapa konvensi PBB yang menempatkan subjek hukum negara sebagai suatu entitas yang dapat diminta pertanggungjawabannya. Bahkan, dalam kondisi tertentu, individu pun dapat dimintai pertanggungjawabannya. Secara khusus United Nations-pun melalui Komisi Hukum Internasional (International Law Commision), sejak 1949 memusatkan perhatian dengan merumuskan dasar hukum dalam State Responsibility, sehingga dapat mengantisipasi kerugian yang timbul bagi suatu negara meskipun tanpa adanya perjanjian internasional yang mengikat para pihak negara bersangkutan. ${ }^{14}$

\footnotetext{
${ }^{11}$ Jus Gentium methode scientifica pertractatum (1849) Prolegomena, alinea 16 dari Steven G Gey., The Myth Of State Sovereignty., Ohio State Law Journal, 2002, hlm. 1.

${ }^{12}$ Malcolm N Shaw, International Law, Cambridge University Press, Cambridge, 1997, hlm. 541.

${ }^{13}$ Megan Bradley, The Conditions of Just Return : State Responsibility and Restitution for Refugees, University of Oxford, United Kingdom, hlm. 3.

${ }^{14}$ Usaha ini diprakarsai Perserikatan Bangsa-Bangsa untuk men-counter pandangan positivistik teori pacta sunt servanda yang hanya mendasarkan suatu tanggung jawab pada perikatan yang terbentuk antara para subyek hukum yang terikat dalam suatu perjanjian.
} 
Dalam laporan akhir sebagaimana tertuang dalam Draft Articles on Responsibility of States for Internationally Wrongful Acts ditentukan bahwa dalam menentukan suatu negara untuk dapat dimintakan pertanggungjawaban dalam ketentuan hukum internasional, karena telah melakukan yang disebut dengan Wrongful Acts, yang mengandung dua elemen utama yang dapat dijadikan dasar pertanggungjawaban negara, yakni : (a) dilakukan oleh atau dapat diatribusikan kepada negara dalam kerangka hukum internasional, ${ }^{15}$ dan (b) secara nyata merupakan pelanggaran terhadap kewajiban internasional suatu negara. ${ }^{16}$

Dalam hal terpenuhinya elemen-elemen utama suatu tindakan yang termasuk dalam persyaratan pertanggungjawaban negara tersebut, maka negara yang melakukan suatu tindakan dan pelanggaran terhadap kewajiban internasional dipersyaratkan untuk melakukan suatu bentuk pertanggungjawaban secara internasional baik dengan instrumen hukum maupun diplomatik. Tindakan awal dalam melakukan pertanggungjawaban internasional adalah menghentikan conduct yang menjadi dasar terjadinya kerugian negara lain dan memastikan tidak mengulang hal yang sama. ${ }^{17}$ Ketentuan ini menjadi landasan untuk segera menghentikan tindakan yang merugikan negara lain dalam waktu sesingkat-singkatnya.

Ketentuan selanjutnya mengatakan bahwa negara yang menyebabkan kerugian bagi negara lain karena tindakan internasional yang dilakukannya wajib untuk mengadakan reparasi terhadap negara yang terkena dampak. Reparasi yang dilakukan meliputi segala kerugian yang timbul baik berupa kerugian material maupun kerugian immaterial. ${ }^{18}$ Bentuk reparasi yang dapat dilakukan meliputi restitusi, kompensasi dan juga bentuk pelunasan lainnya, baik secara satu per satu maupun melalui ketiga instrumen sekaligus. ${ }^{19}$ Dalam hal dilakukannya restitusi, negara penyebab suatu kerugian bagi negara lain diharuskan untuk mengembalikan keadaan seperti semula selayaknya suatu negara berjalan dalam keadaan normal. ${ }^{20}$

Apabila hal tersebut dianggap tidak memuaskan, maka negara tersebut juga diharuskan memberikan suatu kompensasi terhadap kerugian material yang diperhitungkan dan juga terhadap keuntungan yang diharapkan dari suatu

\footnotetext{
${ }^{15}$ International Law Commision Draft Articles on State Responsibility, ILC's 53 rd Session, Jenewa, 2001, Art. 2 (a).

${ }^{16}$ International Law Commision Draft Articles on State Responsibility, ILC's 53 rd Session, Jenewa, 2001, Art. 2 (b).

${ }^{17}$ Ibid., Art. 30.

${ }^{18}$ Ibid., Art. 31.

${ }^{19}$ Ibid., Art. 34.

${ }^{20}$ Ibid., Art. 35.
} 
pengelolaan negara. ${ }^{21}$ Dalam situasi tertentu memungkinkan pula suatu negara yang menyebabkan injury bagi negara lain tidak mempunyai kemampuan untuk melakukan suatu pertanggungjawaban secara hukum, baik meliputi restitusi maupun kompensasi. Pada saat yang demikian, maka ketentuan dalam Draft Articles on Responsibility of States for Internationally Wrongful Acts menetapkan cara terakhir berupa permintaan maaf kepada negara yang terkena dampak. ${ }^{22}$

Dalam perkembangan hukum internasional, kewajiban negara tidak terlepas dari kewajiban untuk tidak melakukan pencemaran dan perusakan lingkungan bagi negara lain. Terlebih dengan seiring banyaknya perjanjian-perjanjian internasional yang merumuskan kewajiban bagi tiap negara untuk tidak mencemari dan merusak ekosistem yurisdiksi negara lain. Kasus-kasus lingkungan hidup yang berdimensi internasional pun mulai timbul dalam pergaulan internasional, mulai dari kasus Chernobyl di Rusia hingga kasus Trial Smelter yang terjadi antara Amerika Serikat dan Kanada.

Prinsip pertanggungjawaban negara pun secara tidak langsung telah diabsorb dalam beberapa perjanjian lingkungan internasional sebagaimana termuat dalam perumusan Pasal 21 Deklarasi Stockholm 1972.

"States have, in accordance with the Charter of the United Nations and the principles of international law, the sovereign right to exploit their own resources pursuant to their own environmental policies, and the responsibility to ensure that activities within their jurisdiction or control do not cause damage to the environment of other States or of areas beyond the limits of national jurisdiction."

Hal ini merupakan suatu bentuk penanganan kasus lingkungan yang secara tegas membuat panduan dan akibat hukum dalam proses pengelolaan lingkungan pada tingkat internasional. Walaupun hingga saat ini belum ada satu kasus lingkungan pun yang dituntut dengan landasan dasar hukum di atas, namun paling tidak dengan adanya ketentuan hukum internasional yang mengatur mengenai kriteria dan bentuk pertanggungjawaban negara terhadap kerugian yang diderita oleh negara lain, akan menjadi landasan hukum lingkungan internasional terhadap semakin hebatnya bentuk pencemaran lingkungan transnasional.

Dalam banyak penelitian yang dilakukan terungkap bahwa keberadaan hutan di Indonesia khususnya di Kalimantan sebagai salah satu pulau dengan angka laju kerusakan hutan terbesar telah mencapai suatu titik yang memprihatinkan dan harus

\footnotetext{
${ }^{21}$ Ibid., Art. 36.

${ }^{22}$ Ibid., Art. 37.
} 
adanya suatu perubahan sikap pengelolaan hutan secara mendasar. Salah satu proses perusakan hutan di hampir seluruh negara yang mempunyai hutan tropis dalam jumlah besar dan memberikan dampak kepada negara lain adalah fenomena kebakaran hutan. Bahkan, tercatat sepanjang sejarah keberadaan manusia, telah ada dua per tiga hutan alami dari bumi ini yang punah, akibat dari kegiatan manusia dalam menjalankan kehidupannya. ${ }^{23}$ Fenomena kebakaran hutan tidak hanya didominasi oleh negara-negara di Asia Tenggara, sejarah mencatat bahwa pada Mei 1998 pemerintah negara bagian Texas mengumumkan bencana nasional yang diakibatkan kebakaran hutan dan telah merusak ekosistem udara sampai radius 100 mil dari pusat kejadian..$^{24}$ Langit di wilayah Dakota Utara dan Colorado pun tak luput dari dampak akibat bencana kebakaran hutan yang mengganggu pernafasan dan jarak pandang masyakat sekitar. ${ }^{25}$ Bahkan Meksiko pernah mengalami kebakaran hutan lebih dari 70 tahun lamanya pada setiap musim kemarau yang berkepanjangan. ${ }^{26}$

Bagi Indonesia sendiri fenomena kebakaran hutan sebagai penyebab pencemaran kabut asap yang sejalan dengan adagium dimana ada asap disitu ada api, bukanlah hal baru. Publik internasional bahkan telah terbiasa dengan agenda tahunan dari bencana kebakaran hutan di Indonesia. Perhatian awal dari masyarakat internasional pertama kali tertuju kepada Indonesia pada saat terjadinya kebakaran hutan pada skala yang sangat besar pada era 1980 yang menghanguskan lebih dari 3,5 juta hektar hutan di Kalimantan Timur dengan radius kabut asap hingga 13.500 mil persegi. ${ }^{27}$

Semenjak kejadian pada era 1980 tersebut, fenomena kebakaran hutan dan dampak kabut asap yang dikirimkan ke negara tetangga seakan-akan telah menjadi agenda rutin pada setiap musim kemarau melanda Indonesia. Kabut asap yang dihasilkan pun tidak hanya mengancam masyarakat pada tingkat nasional semata, melainkan telah merambah pada wilayah negara-negara tetangga dengan intensitas

\footnotetext{
${ }^{23}$ James D. Wolfensohn \& Kathryn S. Fuller, Saving Our Trees of Life, Wash. Post, May 26, 1998, hlm. A17. Lihat juga World Wildlife Fund, Burning Again: WWF Experts Report Forest Fires Out of Control Around the World (visited Apr. 8, 1999) http://www.wwfus.org/new/fires

${ }^{24}$ Jr John H. Cushman, Texans Coping With Smoke Cloud From Fires in Mexico, N.Y. Times, May 18, 1998, hlm. A10.

${ }_{25}$ Americans Ready to Battle Fires, Warn That Relief is Weeks Away, Chi. Trib., May 24, 1998 at 1.

${ }^{26}$ Eugene Linden, Smoke Signals Vast Forest Fires Have Scarred the Globe, But the Worst May be Yet to Come, N.Y.Times, June 22, 1998, hlm. 1.

${ }^{27}$ Around The World; Fire Reported To Ravage Huge Tract In Indonesia Terdapat Dalam Situs Http:/ /Www.Around The World;Fire Reported to Ravage Huge Tract in Indonesia - New York Times.mht.
} 
yang beragam dan memberikan dampak bagi kelangsungan hidup warga negara dalam wilayah yurisdiksi negara lain. ${ }^{28}$ Dampak bagi eksistensi hutan Indonesia pun akibat dari kebakaran hutan telah sampai pada tingkat yang mengkhawatirkan, pada 1997 dan 1998 World Wide Fund for Nature (WWF) mencatat telah terjadi kebakaran hutan di Sumatera dan Kalimantan yang menghanguskan lebih dari 2 juta hektar. ${ }^{29}$ Bahkan estimasi lain yang didapat dari penglihatan oleh satelit menunjukkan angka 3,5 juta sampai dengan 7,5 juta hektar dan terus meluas setiap bulannya. ${ }^{30}$

Sebagai suatu bentuk pencemaran yang bersifat transnasional, terang saja bencana kebakaran hutan di Indonesia membawa dampak berupa pencemaran kabut asap ke negara tetangga. Pada saat terjadinya kebakaran hutan pada 1998 di sekitar Sumatera dan Kalimantan terdeteksi pada alat Pollution Standard Index (PSI) sebagai parameter udara sehat yang terdapat di Malaysia seringkali melebihi nilai ambang batas yang semestinya yaitu 300 PSI yang tergolong kondisi membahayakan, bahkan di negara bagian Kuching, Malaysia Timur indeks mencapai titik 839 PSI. Dari kejadian tersebut Pemerintah Malaysia mencatat 18 juta warganya atau 83,2 \% dari jumlah penduduk yang ada mengalami gangguan pernafasan akut sehingga perlu mendapatkan pertolongan yang serius. ${ }^{31}$

Selain memberikan dampak bagi kesehatan manusia pencemaran kabut asap yang dihasilkan dari proses kebakaran hutan juga memberikan dampak ekonomis yang tidak saja kepada Indonesia melainkan pula kepada negara tetangga lainnya. Semenjak adanya impor kabut asap dari kebakaran hutan Indonesia yang telah mencapai bandar udara Palawan, Philipina 100 lebih pesawat ringan terpaksa menunda penerbangan ke Mindanao. Bandara Puerto Princesa juga ditutup. Biro Perhubungan Udara (ATO) kemarin telah mendesak perusahaan penerbangan lokal untuk mengamati isu meluasnya asap di berbagai bandara di selatan Filipina. ${ }^{32}$

\footnotetext{
${ }^{28}$ Negara tetangga yang sering terkena dampak kabut asap dari kebakaran hutan di Indonesia meliputi Malaysia, Singapura, Brunei Darussalam bahkan Thailand. Lihat Alan Khee - Jin Tan, "Forest Fire of Indonesia: State Responsibility and International Liability”, Singapore, Faculty of Law National University of Singapore, hlm.3. Lihat juga Fazed by the Hare, STRAITS TIMES, Nov. 10, 1997, hlm. 18-19.

${ }^{29}$ Nigel Dudley, the Year the World Caught Fire, 1997, hlm. 7

${ }^{30}$ Dominic Nathan, Haze is Back in Singapore, STRAITS TIMES, Nov. 28, 1998, hlm. 3. Lihat juga Douglas O. Fuller \& Michele Fulk, Satellite Remote Sensing of the 1997-98 Fires in Indonesia: Data, Methods and Future Perspectives terdapat dalam situs http://www.wwf.or. id/forest.html Lihat juga James Schweithelm, The Fire This Time terdapat dalam situs http://www.wwf.or. id/forest.html

${ }^{31}$ Todd Crowell \& Peter Morgan, Twelve Months of Turning Points, ASIAWEEK, Dec. 26, 1997.

32 "Kepungan Asap sudah Sampai Filipina, Kedubes RI di Malaysia Didemo" terdapat dalam situs http:// www.republika.co.id/9709/24/24ASAP.01X.html
} 
Sektor pariwisata juga menerima imbas yang tidak sedikit dari bencana kabut asap yang terjadi, dari sektor penerbangan dan pariwisata yang meliputi penurunan angka hunian hotel dan biro perjalanan tercatat kerugian mencapai Rp. 4.890.000.000,00. Serta banyak bisnis dan investasi yang batal atau tertunda sebagai suatu dampak ekonomi secara tidak langsung, sebesar Rp. 25.690.000.000,00.33 Ditambah lagi dengan biaya yang harus dikeluarkan oleh pemerintah negara setempat untuk melakukan usaha pencemaran dengan pembelian masker yang tidak sedikit. ${ }^{34}$ Dampak tidak langsung lainnya yang dihasilkan dari kebakaran hutan serta asapnya adalah menurunnya kualitas tanaman serta keanekaragaman hayati baik flora maupun fauna yang dimiliki baik oleh pemerintah Indonesia maupun negara tetangga sebagai suatu bentuk efek jangka panjang yang dihasilkan dari suatu bencana yang berkelanjutan.

Sebagai bentuk tindak lanjut dari maraknya kebakaran hutan khususnya di Asia Tenggara dan dampak kabut asap yang dihasilkan, negara-negara yang tergabung dalam Association of South East Asian Nations (ASEAN) mencoba untuk merumuskan suatu kebijakan terkait dengan penanggulangan kebakaran hutan di Asia Tenggara. Pada pertemuan selanjutnya yang diadakan pada Juni 1995, para menteri di negara-negara ASEAN sepakat untuk membuat rencana kerjasama terhadap pencemaran transnasional (lintas batas). ${ }^{35}$ Usaha ini pun dilanjutkan kembali dengan membawa isu yang lebih spesifik, yaitu penanggulangan dampak kabut asap melalui pernyataan para menteri yang terkait masing-masing negara anggota ASEAN dalam Regional Haze Action Plan. ${ }^{36}$ Sekali lagi action plan ini mencoba untuk menegaskan secara langsung mengenai dampak kabut asap yang dapat mengganggu tidak hanya ekosistem yang ada, melainkan juga makhluk hidup di dalamnya. Sebagai usaha untuk memanfaatkan momentum yang ada, dalam rencana kerja ini langsung berusaha untuk membentuk badan penanggulangan kabut asap dan lembaga penelitian pada tingkat regional dan sub regional. ${ }^{37}$

33 "Hak Pembakaran Hutan”, Republika, 30 Agustus 2006.

34 “Kebakaran Hutan Turunkan Kualitas Lingkungan dan Nilai Ekonomi”, Suara Pembaruan, 23 Januari 2008.

${ }^{35}$ Forward to ASEAN Secretariat, ASEAN Cooperation Plan on Transboundary Pollution (1997)

${ }^{36}$ Regional Haze Action Plan, ASEAN (Dec. 1997) (diakses pada tanggal 20 Maret 2008) terdapat dalam situs http://www.aseansec.org/function/pa haze.html.

${ }^{37}$ Badan Penanggulangan Kabut Asap ini ikut mengambil bagian pada saat kebakaran hutan di Indonesia pada tahun 1998, sedangkan Badan Penelitian mengambil lokasi di Kalimantan dan Riau sebagai pusat penelitian. Lihat Joint Press Statement, Third ASEAN Ministerial Meeting on Haze, para. 8, ASEAN (diakses 20Maret 2008) terdapat dalam situs <http:// www.aseansec.org/function/prhaze3.htm $>$. 
Momentum selanjutnya adalah pada usaha negara-negara anggota ASEAN untuk merumuskan suatu panduan dan komitmen hukum secara bersama-sama yang dituangkan dalam suatu perjanjian yang berjudul ASEAN Agreement on Transboundary Haze Pollution (persetujuan ASEAN tentang pencemaran kabut asap lintas batas) yang mengatur pendistribusian tanggung jawab dan penanganan pencemaran kabut asap pada kawasan regional Asia Tenggara. Perjanjian ini ditandatangani oleh 10 negara peserta ASEAN pada Juni 2002, dan kemudian came into force pada 25 November 2003. ${ }^{38}$ Setelah tiga tahun berjalan, tujuh dari sepuluh negara penandatangan telah melakukan ratifikasi dan harmonisasi dengan peraturan perundang - undangan nasional negara peserta setempat. ${ }^{39}$

Ironisnya, setelah berjalan 9 tahun hingga kini Indonesia selaku aktor dan subjek utama dalam ASEAN Agreement on Transboundary Haze Pollution (Persetujuan ASEAN tentang Pencemaran Kabut Asap Lintas Batas) belum juga melakukan proses ratifikasi. Keberadaan semangat tanggung jawab bersama yang diusung dalam ASEAN Agreement on Transboundary Haze Pollution (Persetujuan ASEAN tentang Pencemaran Kabut Asap Lintas Batas) sebenarnya dapat menjadi alasan untuk tidak dibebankannya tanggung jawab kepada Indonesia. Namun, hal ini justeru berlaku sebaliknya pada saat banyak peraturan perundang-undangan Indonesia yang melanggar kebijakan zero burning policy.

Dalam sistem otonomi sekarang ini, keberadaan kebijakan yang memberikan kewenangan kepada daerah untuk dapat melakukan upaya pengelolaan lingkungan secara mandiri terkadang memberikan dampak buruk. Hal ini dapat dilihat dari keberadaan beberapa peraturan daerah yang secara eksplisit memperbolehkan adanya praktek pembakaran lahan dengan jumlah area tertentu bertentangan dengan Peraturan Pemerintah Nomor 4 Tahun 2001 tentang Pengendalian Kerusakan dan atau Pencemaran Lingkungan Hidup yang Berkaitan dengan Kebakaran Hutan dan atau Lahan. ${ }^{40}$ Dalam kondisi seperti itu, maka salah satu faktor yang mempengaruhi

\footnotetext{
${ }^{38}$ ASEAN Agreement on Transboundary Haze Pollution, Art. 29.

${ }^{39}$ Negara yang melakukan persetujuan meliputi seluruh negara anggota ASEAN. Sampai dengan Agustus 2005 tercatat yang telah melakukan ratifikasi adalah : (i) Brunei Darussalam tanggal 27 February 2003; (ii) Laos tanggal 19 Desember 2004; (iii) Malaysia tanggal 3 Desember 2002; (iv) Myanmar tanggal 5 Maret 2004; (v) Singapura tanggal 13 Januari 2003; (vi) Thailand tanggal 10 September 2003; (vii) Vietnam tanggal 24 Maret 2003. Lihat ASEAN Agreement on Transboundary Haze Pollution, June 10, 2002, terdapat dalam situs http://www.aseansec.org/pdf/agr haze.

${ }^{40}$ Peraturan tersebut tercantum dalam Peraturan Daerah Riau dan Peraturan Daerah Kotawaringin Barat. Lihat Deni Bram, "Kebijakan Pengelolaan Hutan Belum Proekologi”, Media Indonesia (1 September 2007): 7. Lihat pula Perda Karhutla Picu Kebakaran Hutan, Suara Pembaruan Daily 29/6/07
} 
adanya kelemahan dari model command and control di Indonesia dalam upaya pencegahan dan penanganan kebakaran hutan di Indonesia adalah tidak adanya konsistensi dari substansi yang terdapat dalam suatu sistem hukum sebagaimana dikemukakan oleh Friedman. ${ }^{41}$

Pada sisi lain, konteks lemahnya penegakan hukum terhadap pembakaran lahan dan hutan yang dilakukan oleh berbagai korporasi dalam rangka minimalisasi biaya, terlihat bahwa peran pemerintah dalam mengurangi praktek perusakan lingkungan tidak mempunyai suatu pengaruh besar bagi kalangan pelaku usaha dalam menjalankan kegiatan usaha yang dilakukan. Justeru dalam kondisi tertentu menurut David Kolstad dalam Environmental Economic, ${ }^{42}$ determinisme ekonomi menjadi suatu variabel yang mencoba untuk menghadirkan regulasi yang sesuai dengan motifmotif ekonomi mencoba untuk mempengaruhi adanya kebijakan penaatan (compliance) di bidang lingkungan hidup.

Kondisi maraknya praktik pembakaran lahan yang dilakukan oleh perusahaanperusahaan yang memegang baik hak pengelolaan hutan maupun hak terhadap hutan tanaman industri di dalamnya dikategorikan sebagai tindakan negara yang merugikan negara lain dalam tataran hukum internasional. Hal ini sejalan dengan rumusan dari Draft Article on Responsibility of State for Internationally Wrongful Act yang dirilis oleh International Law Commission pada akhir tahun 2002 sebagai landasan teoritis.

\section{Penutup}

Dari uraian di atas dapat ditarik kesimpulan sebagai berikut, Pertama, prinsip pertanggungjawaban negara sebagai salah satu prinsip utama dalam hukum internasional pada intinya memuat kewajiban negara yang memberikan dampak kepada negara lain untuk melakukan suatu reparasi kepada negara yang dirugikan dan mengembalikan kondisi negara yang bersangkutan seperti semula. Keberadaan hukum lingkungan internasional sebagai salah satu cabang dari hukum internasional turut pula membawa pemberlakuan dari prinsip tanggung jawab negara dalam beberapa kasus hukum lingkungan internasional seperti yang dapat ditemui dalam

${ }^{41}$ Menurut Lawrence M Friedman suatu sistem hukum dapat berjalan optimal apabila ditunjang oleh Struktur, Substansi dan Budaya Hukum di dalamnya. Substansi diartikan sebagai aturan, norma dan pola perilaku nyata dalam sebuah sistem hukum. Lihat Lawrence M Friedman, Hukum Amerika Sebuah Pengantar, Tatanusa, Jakarta, 2001, hlm. 7.

${ }^{42}$ Charles D Kolstad, Loc. Cit., hlm. 139. 
Trial Smelter Case 1938 yang melibatkan Amerika dengan Kanda, Corfu Channel Case 1949 antara Inggris dan Albania, dan Lake Lanoux Case 1957 antara Perancis dan Spanyol. Seiring dalam perkembangan perspektif masyarakat internasional yang menganggap bahwa lingkungan hidup adalah suatu kesatuan internasional (wholeness) tanpa adanya batas administratif, keberadaan prinsip pertanggungjawaban negara mulai tergeser dengan prinsip Common But Differentiated Responsibility yang menekankan pada tanggung jawab secara bersama-sama yang didasari oleh suatu pertanggungjawaban hukum oleh negara tertentu. Hal ini merupakan suatu antithesis dari prinsip pertanggungjawaban negara yang berada pada ranah hukum internasional pada umumnya sehingga menafikan adanya suatu tanggung jawab hukum dari negara tertentu.

Kedua, berbagai mekanisme penyelesaian sengketa hukum lingkungan internasional pada awal-awal perkembangan hukum lingkungan internasional menunjukkan belum adanya suatu aturan yang mengikat dan memberikan kepastian dalam hal proses yang dilalui dalam penyelesaian sengketa hukum lingkungan internasional. Bahkan, dalam beberapa kasus besar, Majelis Arbitrase telah dijadikan salah satu alternatif utama dalam penyelesaian sengketa hukum lingkungan internasional. Dalam perkembangan selanjutnya, beberapa sumber hukum lingkungan internasional memuat sanksi yang lebih bersifat ekonomis dan diplomatis dalam tataran internasional. Salah satu alternatif yang timbul dalam mekanisme penyelesaian hukum lingkungan internasional yang tersedia adalah pemberlakuan prinsip pertanggungjawaban negara yang diawali dari adanya claim dari negara yang mengalami kerugian yang merupakan suatu bentuk absorpsi hukum lingkungan internasional terhadap keberlakuan prinsip utama dalam hukum internasional tersebut.

Ketiga, terjadinya pencemaran kabut asap yang diakibatkan dari kebakaran hutan di Indonesia kerap kali melanda beberapa negara ASEAN pada umumnya dan negara yang berdekatan dengan Indonesia pada khususnya yang tentu memberikan dampak yang tidak hanya mengganggu ekosistem negara sekitar, namun juga berdampak pada kegiatan usaha pada sektor riil seperti pariwisata dan transportasi udara. Kebakaran hutan yang terjadi di Indonesia selama hampir 20 tahun telah dipengaruhi banyak faktor yang antara lain adalah variabel ekonomi dari korporasi besar pada bidang kelapa sawit yang membuka lahan dengan mekanisme pembakaran sebagai upaya minimalisasi biaya. Dalam tataran hukum internasional, 
tindakan para korporasi tersebut yang didasari oleh hak konsesi yang diberikan negara merupakan suatu bentuk tindakan negara yang diikuti dengan pertanggungjawaban. Tindakan negara tersebut pun secara tegas telah melanggar beberapa sumber hukum internasional yang berorientasi menciptakan iklim yang lebih baik. Berdasarkan kedua hal tersebut, dan berdasarkan teori pertanggungjawaban negara yang terdapat pada Draft Article on Responsibility of State for Internationally Wrongful Act yang dirilis oleh International Law Comission pada akhir 2002, maka pemerintah Indonesia dapat dimintakan pertanggungjawaban atas pencemaran kabut asap yang terjadi. Sebagai suatu bentuk konsekuensi logis dari pertanggungjawaban Indonesia adalah reparasi yang wajib dilakukan oleh pemerintah Indonesia kepada negara tercemar seperti keadaan semula baik kerugian yang berifat materiil hingga kepada kerugian imateriil yang diharapkan dari suatu negara terhadap kegiatan ekonomi yang sedang berjalan sebagai suatu bentuk pertanggungjawaban negara pada tingkatan paling tinggi. Dalam kondisi yang terpaksa dan tidak memungkinkan adanya penggantian secara ekonomis, permintaan maaf secara diplomasi menjadi bentuk pertanggungjawaban dalam tataran terlemah.

Adapun saran yang ingin peneliti sampaikan adalah sebagai berikut: Pertama, prinsip pertanggungjawaban negara sebagai salah satu prinsip utama dalam hukum internasional pada era sekarang ini hendaknya tetap dapat dipertahankan eksistensinya sebagai salah satu alternatif penyelesaian sengketa yang terjadi pada tataran internasional. Tanpa menafikan adanya variabel lain dalam hubungan internasional yang mempengaruhi hubungan timbal balik antara satu negara dengan negara lainnya, keberadaan prinsip tanggung jawab negara dalam tataran hard law hendaknya mendapat prioritas sebagai salah satu upaya perwujudan equality before the law pada tataran internasional. Kedua, penerapan prinsip pertanggungjawaban negara dalam hukum lingkungan internasional pada dewasa ini dapat dipandang masih terikat pada ketentuan prinsip tanggung jawab negara yang dirumuskan pada hukum internasional pada umumnya, yang mensyaratkan adanya tindakan negara dan adanya pelanggaran terhadap hukum internasional. Adanya persyaratan pelanggaran terhadap hukum internasional dalam pertanggungjawaban negara pada kasus-kasus hukum lingkungan internasional menurut peneliti merupakan suatu hal yang kurang tepat dan terlampau bersifat prosedural. Adanya kenyataan bahwa lingkungan hidup sebagai objek kepentingan bersama (common interest) sehingga untuk mengatasi krisis global (global atau interlocking crisis), seharusnya penerapan 
prinsip tanggung jawab negara dapat mengenyampingkan adanya perjanjian internasional terlebih dahulu antara negara pencemar dan negara tercemar dalam kasus-kasus hukum lingkungan internasional. Ketiga, fenomena kebakaran hutan di Indonesia yang berujung pada pencemaran kabut asap di beberapa negara tetangga memiliki suatu kekhasan tersendiri dalam bentuk penanggulangan. Variabel ekonomi yang dilakukan oleh korporasi-korporasi besar pada saat pembukaan lahan menjadi alasan dominan maraknya pembakaran lahan yang tidak hanya memberikan kerugian materiil, namun juga telah mengakibatkan hilangnya harapan keuntungan dari berbagai sektor di negara tetangga. Dalam proses penanggulangan terhadap kasus tersebut tentu perlu adanya perlakuan khusus terhadap entitas ekonomi yang tidak hanya bisa dilakukan dengan pendekatan hukum yang bersifat command and control semata. Dalam kasus kebakaran hutan di Indonesia yang menjadi awal pencemaran kabut asap lintas negara ini penulis menawarkan adanya pendekatan ekonomi yang bersifat insentif dan disinsentif pada tingkat nasional yang dapat memicu beberapa korporasi untuk menjadikan salah satu variabel pertimbangan dalam kegiatan produksi. Sedangkan dalam tataran internasional, pemberlakuan pajak di negara-negara tercemar terhadap produk negara pencemar dapat menjadi alternatif preventif dalam mendorong political will dari negara yang menjadi sumber pencemaran.

\section{Daftar Pustaka}

Bell, Stuart \& Donald McGillivray, Environmental Law, Blackstone Press, London, 2001.

Bradley, Megan, The Conditions of Just Return : State Responsibility and Restitution for Refugees, University of Oxford, United Kingdom 2007.

Dobson, Andrew, Justice and the Environment., Oxford University Press, New York, 1998.

Hardjasoemantri, Koesnadi, Hukum Tata Lingkungan, Cet. 19, UGM Press, Yogyakarta, 2006.

Jackson, Robert H., “Quasi States : Sovereignity, International Relations, and The Third World", Press Syndicate of The University of Cambridge, Cambridge, 1990.

Johnston, R.J., Nature, State, and Economy : A Political Economy of the Kolstad, Charles. Environmental Economics, Oxford University Press, New York, 2000.

Posner, Richard, Economic Analysis of Law, Aspen Law and Business, Kluwer, 1998. 
Potter, Donald W., "State Responsibility, Sovereignity, and Failed States", University of Tasmania, Australia, 2005.

Putra, Ida Bagus Wyasa, Hukum Lingkungan Internasional : PerspektifBisnis Internasional, Refika Aditama, Bandung 2003.

Riyanto, Budi, Hukum Kehutanan dan Sumber Daya Alam. Bogor: Lembaga Pengkajian Hukum Kehutanan dan Lingkungan, 2004.

Shaw, Malcom N., International Law, Cambrige University Press, Cambrige, 2003.

Simonovic, Ivan “Relative Sovereignty of The Twenty First Century”, Hastings International and Comparative Law Review Summer 2002.

Soltau, Friedrich, Fairness in International Climate Change Policy, Cambridge University Press, United States, 2009.

Wattimena, Reza A.A., Melampaui Negara Hukum Klasik : Locke - Rousseau - Habermas, Kanisius, Yogyakarta, 2007.

Westra, Laura, Environmental Justice and The Rights for Unborn and Future Generations, Earthscan, United Kingdom, 2006.

Agora, What Obligation Does Our Generation Owe to the Next? An Approach to Global Environmental Responsibility, American Journal of International Law January, 1992.

Bodansky, Daniel, The United Nations Framework Convention on Climate Change: A Commentary, 18 Yale J. Int'l L. 451, 1993.

Coase, Ronald H. The Problem of Social Cost, 3 J.L. \& ECON, 1960.

Harris, Paul G. Collective Action on Climate Change: The Logic of Regime Failure, 47 Nat. Resources J. 195., 2007.

, Climate Change And The Impotence Of International Environmental Law: Seeking A Cosmopolitan Cure, Penn State Environmental Law Review Winter, 2008.

Koh, Harold Hongju., Why Do Nations Obey International Law?, 106 Yale L.J. $2599,1997$.

Nollkaemper, Andre, Protecting Forest through Trade Measure: The Search for Substantive Benchmarks, Georgetown International Environmental Law Review, Vol. 8, 1996.

Sloane, George B dan Barry N. Rosen, Environmental Product Standards, Trade and European Consumer Good Marketing: Processes, Threats and Opportunities, Columbia Journal of World Business, Vol. 30, No. 1, 1995

Taylor, Prue, "An Ecological Approach To International Law: Responding To Challenges Of Climate Change", 1998.

Thürer, Daniel, The "Failed States" and International Law , International Review of the Red Cross, 1999.

Weiss, Edith Brown, International Environmental Law: Contemporary Issues and the Emergence of a New World Order, 81 GEO. L. J. 675, 679, 1993. 